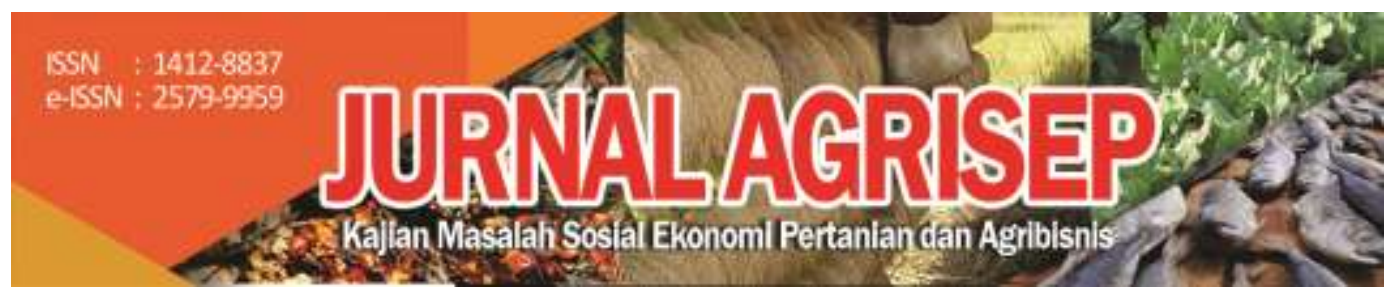

DOI: 10.31186/jagrisep.19.1.83-98

\title{
ANALISIS PENGARUH KUALITAS PELAYANAN PENYULUH PERTANIAN TERHADAP KEPUASAN PETANI DALAM PENGEMBANGAN USAHA TANI DI KABUPATEN PIDIE
}

\section{Analysis Of The Effect Of Agricultural Authority Quality On Farmer Satisfaction In Development Of Farmer Business In Pidie District}

\author{
Mujiburrahmad ${ }^{1}$ Akhmad Baihaqi ${ }^{1}$, Ira Manyamsari ${ }^{1}$ \\ Program Studi Agribisnis Fakultas Pertanian Universitas Syiah Kuala \\ Email: mujiburrahmad@unsyiah.ac.id
}

\begin{abstract}
Agricultural activities still have a very strategic role in supporting national development, both for economic growth and equitable development. The strategic role of the agricultural sector for economic growth includes: food producers for the population of Indonesia, foreign exchange earners through exports, providers of industrial raw materials, increased employment and business opportunities, increased GDP, poverty alleviation and improvement of agricultural human resources through agricultural extension activities. The purpose of this study is to, (1) Knowing farmers' satisfaction with extension services in farming development in Pidie District, and (2) Knowing the relationship between the quality of agricultural extension services to the development of farming in Pidie District. This research was carried out in the Dayah Syarief Village, Mutiara District, Pidie District. The sample in this study were all farmers who numbered 90 people. The independent variables in this study are: (X1), Response (X2), Confidence (X3), Empathy (X4), Physical Evidence (X5) and Farmer Decision (Y) as the dependent variable. Data is collected using the survey method through a questionnaire filled out by Farmers. The data processing in this study will use the SPSS program (Statistical Package for the Social Science). The satisfaction of farmer with extension services in farming development in Busu Dayah Syarief Village, Mutiara District, Pidie District based on the results of research on Farmer Satisfaction variables obtained an average value of (4.18), so that respondents' assessment of the Farmer Satisfaction variable was influenced by variables of reliability, responsiveness, Belief, empathy and physical evidence. The relationship of the quality of agricultural extension services to the development of farming in Busu Dayah Syarief Village,
\end{abstract}


Mutiara District, Pidie District, based on the results of the analysis concluded that of the five variables studied, it turns out the Confidence variable (X3) has the most dominant influence of $0.422 \%$ on Farmer Satisfaction. The relationship between the dependent and independent variables is each variable Reliability (X1), Responsiveness (X2), Confidence (X3), Empathy (X4), and Physical Evidence (X5) to Farmer Satisfaction with a correlation index of 0.978 or $97.8 \%$ This means that the relationship is very strong. Then the index of determination of each variable Reliability (X1), Responsiveness (X2), Confidence (X3), Empathy (X4), and Physical Evidence (X5) is 0.957 or $95.7 \%$, this means that the 5 variables have a significant effect towards farmer satisfaction in farming development, and by $4.3 \%$ which is influenced by other variables not examined in this study.

Keywords: Extension, Farmers, Agriculture, Satisfaction.

\begin{abstract}
ABSTRAK
Kegiatan pertanian hingga kini masih memiliki peranan yang sangat strategis dalam mendukung pembangunan nasional, baik untuk pertumbuhan ekonomi maupun pemerataan pembangunan. Peran strategis sektor pertanian bagi pertumbuhan ekonomi diantaranya: produsen pangan bagi penduduk Indonesia, penghasil devisa negara melalui ekspor, penyedia bahan baku industri, peningkatan kesempatan kerja dan usaha, peningkatan PDB, pengentasan kemiskinan dan perbaikan SDM pertanian melalui kegiatan penyuluhan pertanian. Tujuan penelitian ini adalah untuk, (1). Mengetahui kepuasan petani terhadap pelayanan penyuluh dalam pengembangan usahatani di Kabupaten Pidie, dan (2) Mengetahui hubungan kualitas pelayanan penyuluh pertanian terhadap pengembangan usaha tani di Kabupaten Pidie. Penelitian ini dilaksanakan di lakukan di Desa Dayah Syarief Kecamatan Mutiara Kabupaten Pidie. Sampel pada penelitian ini adalah semua petani yang berjumlah 90 orang. Variabel independen dalam penelitian ini yaitu Kehadalan (X1), Daya Tanggap (X2), Keyakinan (X3), Empati (X4), Bukti Fisik (X5) dan Keputusan Petani (Y) sebagai variabel dependennya. Data dikumpulkan dengan menggunakan metode survey melalui kuesioner yang diisi oleh Petani. Pengolahan data dalam penelitian ini akan menggunakan program SPSS (Statistical Package for the Sosial Science). Kepuasan petani terhadap pelayanan penyuluh dalam pengembangan usahatani di Desa Busu Dayah Syarief Kecamatan Mutiara Kabupaten Pidie berdasarkan hasil penelitian terhadap variabel Kepuasan Petani diperoleh nilai rata-rata sebesar (4.18), sehingga penilaian responden terhadap variabel Kepuasan Petani dipengaruhi oleh variabelvariabel kehandalan, daya tanggap, Keyakinan, empati dan bukti fisik. Hubungan kualitas pelayanan penyuluh pertanian terhadap pengembangan usaha tani di Desa Busu Dayah Syarief Kecamatan Mutiara Kabupaten Pidie berdasarkan hasil analisis disimpulkan bahwa dari kelima variabel yang diteliti, ternyata variabel Keyakinan $\left(X_{3}\right)$ mempunyai pengaruh yang paling dominan sebesar 0.422\% terhadap Kepuasan Petani. Hubungan antara variabel dependen dan independen yaitu masing-masing variabel Kehandalan $\left(X_{1}\right)$, Daya tanggap $\left(X_{2}\right)$, Keyakinan $\left(X_{3}\right)$, Empati $\left(X_{4}\right)$, dan Bukti Fisik $\left(X_{5}\right)$ terhadap Kepuasan Petani dengan indeks korelasi sebesar 0,978 atau 97,8 \% Ini
\end{abstract}

84 | Mujiburrahmad, Akhmad Baihaqi, Ira Manyamsari; Analisis Pengaruh..... 
berarti hubungan tersebut sangat kuat. Kemudian indeks determinasi masing-masing variabel Kehandalan $\left(X_{1}\right)$, Daya tanggap $\left(X_{2}\right)$, Keyakinan $\left(X_{3}\right)$, Empati $\left(X_{4}\right)$, dan Bukti Fisik $\left(X_{5}\right)$ sebesar 0,957 atau 95,7\%, ini berarti ke 5 variabel berpengaruh secara signifikan terhadap kepuasan petani dalam pengembangan usahatani, dan sebesar 4,3\% yang dipengaruhi oleh variabel lain yang tidak diteliti di dalam penelitian ini.

Kata kunci: Penyuluh, Petani, Pertanian, Kepuasan.

\section{PENDAHULUAN}

Penyelenggaraan kegiatan penyuluhan pertanian mempunyai kedudukan yang sangat strategis dalam proses pembangunan pertanian, khususnya dalam pengembangan kemampuan,pengetahuan, keterampilan, serta sikap pelaku utama dan pelaku usaha. Melalui penyuluhan pertanian, pelaku utama dan pelaku usaha di bidang pertanian diharapkan mau dan mampu menolong dan mengorganisasikan diri dalam mengakses informasi pasar, teknologi, permodalan, dan sumberdaya lainnya, sebagai upaya untuk meningkatkan produktivitas, efisiensi usaha, pendapatan, dan kesejahteraannya, serta meningkatkan kesadaran dalam pelestarian fungsi lingkungan hidup (UUSP3K, 2006).

Kegiatan penyuluhan pertanian perlu ditata dan dikembangkan sedemikian rupa agar harapan, kepuasan dan kapasitas petani sebagai sasaran penyuluhan pertanian dapat terpenuhi sebagaimana mestinya. Abubakar et al, (2015) menyatakan bahwa pelaksanaan kegiatan penyuluhan pertanian merupakan serangkaian proses yang berkelanjutan sesuai dengan kebutuhan petani; untuk itu materi dan metode penyuluhan pertanian merupakan bagian dari kualitas kegiatan penyuluhan pertanian. Kualitas penyuluhan pertanian dapat diketahui dengan cara membandingkan kepuasan para petani atas layanan yang diterima dengan layanan yang diharapkan petani. Lebih jauh lagi Abubakar et al (2015) menjelaskan bahwa kegiatan pada penyuluhan pertanian diharapkan agar mampu menjembatani berbagai fenomena-fenomena yang terjadi di lingkungan petani dengan perkembangan ilmu pengetahuan, baik yang bersifat temporer maupun bersifat tetap. Keberadaan penyuluh pertanian sebagai ujung tombak dari proses penyelenggaraan pembangunan pertanian diharapkan mampu menyampaikan pesan-pesan inovasi sesuai kebutuhan para petani serta mampu untuk menerjemahkan kebijakan dari pemerintah terkait dengan pembangunan pertanian. Dengan kata lain, penyuluhan pertanian diharapkan mampu memenuhi kebutuhan petani untuk mengembangkan usahataninya sehingga petani merasa puas.

Dalam hubungannya dengan metode-metode dalam penyuluhan, untuk meningkatkan efektivitas metode, pemilihan dan penggunaan metode harus didasarkan atas kondisi para petani, yaitu perhatian, minat, kepercayaan, hasrat, tindakan dan kepuasan. Kondisi petani penting diperhatikan agar penyuluhan yang dilakukan dapat ikut membantu para petani memenuhi 
kebutuhannya, sehingga dengan demikian menimbulkan kepuasan bagi petani dan penyuluhan seperti itu merupakan penyuluhan yang berkualitas.

Puspadi (2010) menjelaskan bahwa pada hakekatnya kualitas dari kegiatan penyuluhan pertanian merupakan fungsi kualitas sumberdaya manusia penyuluh pertanian. Kualitas kegiatan penyuluhan pertanian diukur dengan lima indikator, yaitu: (1) materi penyuluhan pertanian, (2) domain yang disentuh dalam melaksanakan rangkaian kegiatan penyuluhan pertanian, (3) memfasilitasi keputusan-keputusan dari petani, (4) keberpihakan kepada petani, dan (5) intensitas kunjungan penyuluh pertanian ke wilayah binaannya. Kualitas pelayanan penyuluhan diharapkan dapat menimbulkan kepuasan bagi petani yang selanjutnya akan bermanfaat dalam upaya ikut meningkatkan kapasitasnya. Subagio et al. (2008) menyatakan bahwa kapasitas petani adalah daya-daya yang dimiliki pribadi seorang petani untuk dapat menetapkan tujuan usahatani secara tepat dan mencapai tujuan yang telah ditetapkan dengan cara yang tepat pula.

Kapasitas diri merupakan perwujudan dari aspek pengetahuan, aspek sikap, dan keterampilan yang terinternalisasi dalam diri seseorang (Tjitropranoto, 2005). Disamping aspek pengetahuan, sikap dan juga keterampilan, kapasitas diri menurut Tjitropranoto (2005) juga dibentuk oleh rasa percaya diri, komitmen, dan kewirausahaan; sedangkan untuk kapasitas sumberdaya dan sarana meliputi lahan, modal usaha, dan pasar.

Kepuasan petani terhadap suatu jasa ditentukan oleh tingkat kepentingan petani. Faktor yang menentukan kepuasan petani adalah kualitas pelayanan yang terfokus pada ketepatan pelayanan, dimensinya yaitu keandalan (reliability), kesigapan penyuluh dalam merespon masalah yang disampaikan petani, dimensinya yaitu daya tanggap (responsiviness), keramahan penyuluh dalam menyampaikan informasi, dimensinya yaitu jaminan (insurance), kemudahan petani dalam menghubungi penyuluh serta kemampuan penyuluh berkomunikasi dengan petani yang dimensinya yaitu empati (empathy), serta penampilan penyuluh pada saat melayani petani, dimensinya bukti langsung/nyata (tangibles) (Bitnar, 2007).

Di Indonesia tugas pokok dan fungsi penyuluh pertanian adalah melakukan kegiatan penyuluhan pertanian untuk dapat mengembangkan kemampuan petani dalam menguasai, memanfaatkan dan menerapkan teknologi baru sehingga mampu bertani lebih baik, berusaha lebih menguntungkan serta membina kehidupan berkeluarga yang lebih sejahtera. Penyuluh pertanian dituntut untuk memiliki kemampuan yang memadai dalam menetapkan materi sesuai kebutuhan petani serta dapat menggunakan metode penyuluhan yang sesuai dengan keadaan petani. Materi penyuluhan merupakan segala pesan yang ingin dikomunikasikan oleh penyuluh kepada masyarakat sasarannya. Pemilihan jenis pengkajian ini berdasarkan pemikiran untuk mengetahui kualitas pelayanan penyuluh terhadap kepuasan petani 
dalam pengembangan usaha tani di Desa Busu Dayah Syarief Kecamatan Mutiara Kabupaten Pidie. Tujuan dari penelitian ini adalah: (1). Untuk Mengetahui kepuasan petani terhadap pelayanan penyuluh dalam pengembangan usahatani di Kabupaten Pidie, dan (2) Untuk Mengetahui hubungan kualitas pelayanan penyuluh terhadap pengembangan usaha tani di Kabupaten Pidie.

\section{METODE PENELITIAN}

Metode yang digunakan dalam pengumpulan data adalah sensus dan menggunakan paradigma kuantitatif. Penelitian ini dilaksanakan di Desa Busu Dayah Syarief Kecamatan Mutiara Kabupaten Pidie, yang dilakukan mulai bulan Oktober sampai dengan November 2017. Objek penelitian ini ialah semua pelaku kegiatan penyuluhan pertanian yang ada di Desa Busu Dayah Syarief Kecamatan Mutiara Kabupaten Pidie. Ruang lingkup penelitian berbatas pada kualitas pelayanan penyuluhan pertanian dan kepuasan petani dalam pengembangan usaha tani. Responden dalam penelitian ini adalah 90 orang. Pengumpulan data dalam penelitian ini dengan dua sumber yaitu data sekunder dan data primer

Data yang diperoleh berupa data kuantitatif dan akan diolah secara statistik. Analisis data yang digunakan dalam penelitian ini menggunakan Regresi Linear Berganda, dengan menggunakan program SPSS (Statistical Package for the Sosial Science) software. Dalam pengolahan data, penggunaan program untuk mengubah data dari ordinal ke interval Microsoft Office Excel 2010.

\section{HASIL DAN PEMBAHASAN}

Karakteristik responden yang diteliti dalam penelitian ini adalah mencakup jenis kelamin, usia, pendidikan terakhir, pekerjaan, dan pendapatan responden. Berdasarkan hasil penelitian dari tabel 1 menunjukkan 86,7\% (78) responden berjenis kelamin laki-laki dan $13,3 \%$ perempuan. Hasil penelitian ditemukan bahwa $70 \%$ (20-30 tahun) usia responden dalam kategori umur muda.

Pendidikan terakhir responden 52,2\% SMU/Sederajat, 26,7\% berpendidikan $\mathrm{SMP} /$ sederajat dan $21,1 \%$ sarjana. Pada umumnya seseorang yang berpendidikan lebih baik dan berpengetahuan teknis yang lebih banyak, akan lebih mudah dan mampu berkomunikasi dengan baik. Semakin tinggi pendidikan formal, akan semakin tinggi pula kemampuannya untuk menerima, menyaring dan menerapkan inovasi yang dikenalkan kepadanya (Manyamsari \& Mujiburrahmad). Dari 90 responden sebanyak 42 orang $(46,7 \%)$ pekerjaannya adalah petani, 19 orang sebagai pelajar/mahasiswa, 15 orang bekerja di bidang wiraswasta dan 14 orang sebagai pegawai negeri sipil. Hasil penelitian dilapangan menunjukkan responden $77,8 \%$ pendapatannya adalah 
Rp.1.500.000 - Rp. 3.000.000, untuk melihat detail data karakteristik responden disajikan pada Tabel 1.

\section{Tabel 1 Karakteristik Responden}

\begin{tabular}{|c|c|c|c|}
\hline No. & Uraian & Frekuensi & Persentase \\
\hline \multirow[t]{3}{*}{1} & Jenis Kelamin: & & \\
\hline & Laki-laki & 12 orang & $13,3 \%$ \\
\hline & Perempuan & 78 orang & $86,7 \%$ \\
\hline \multirow[t]{5}{*}{2} & Usia: & & \\
\hline & $<19$ tahun & 7 orang & $7,8 \%$ \\
\hline & $20-25$ tahun & 24 orang & $26,7 \%$ \\
\hline & $26-30$ tahun & 39 orang & $43,3 \%$ \\
\hline & $>31$ tahun & 20 orang & $22,2 \%$ \\
\hline \multirow[t]{5}{*}{3} & Pendidikan Terakhir: & & \\
\hline & $\mathrm{SMP} /$ Sederajat & 24 orang & $26,7 \%$ \\
\hline & SMU/Sederajat & 47 orang & $52,2 \%$ \\
\hline & Sarjana & 19 orang & $21,1 \%$ \\
\hline & Pasca Sarjana & - & - \\
\hline \multirow[t]{6}{*}{4} & Pekerjaan: & & \\
\hline & Pelajar/Mahasiswa & 19 orang & $21,1 \%$ \\
\hline & Wiraswasta & 15 orang & $16,7 \%$ \\
\hline & Pegawai Negeri & 14 orang & $15,6 \%$ \\
\hline & Petani & 42 orang & $46,7 \%$ \\
\hline & Lain-lain & - & - \\
\hline \multirow[t]{6}{*}{5} & Pendapatan & & \\
\hline & < Rp. 1000.000 & 4 orang & $4,4 \%$ \\
\hline & RP. 1500.000 - Rp. 2000.000 & 36 orang & $40 \%$ \\
\hline & Rp. 2.500 .00 -RP. 3.000 .000 & 34 orang & $37,8 \%$ \\
\hline & Rp. 3.500 .000 - Rp. 4.000 .000 & 12 orang & $13,3 \%$ \\
\hline & > Rp. 4.000 .000 & 4 orang & $4,4 \%$ \\
\hline
\end{tabular}

Sumber : Data primer (Diolah), 2017

\section{Tingkat Kepuasan Petani Terhadap Pelayanan Penyuluh dalam} Pengembangan Usahatani

\section{Faktor Keandalan}

Faktor Keandalan $\left(X_{1}\right)$ merupakan salah satu variabel yang mempengaruhi Kepuasan Petani dalam pengembangan usahatani di Desa Busu Dayah Syarief Kecamatan Mutiara Kabupaten Pidie yang terdiri dari 3 item pertanyaan. Hasil pengolahan data seperti pada Tabel 2.

\section{Tabel 2 Indikator Faktor Kehandalan}

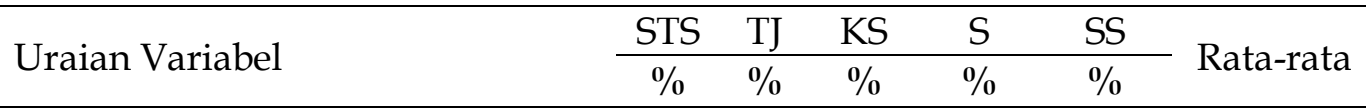




\begin{tabular}{llllllll}
\hline $\begin{array}{l}\text { Keandalan penyuluh pertanian } \\
\text { dalam melakukan sosialisasi }\end{array}$ & 0 & 5,6 & 23,3 & 61,1 & 10 & 3,76 \\
kepada masyarakat \\
$\begin{array}{l}\text { Penyuluh pertanian membawa } \\
\text { peralatan yang lengkap saat } \\
\text { melakukan sosialisasi }\end{array}$ & 0 & 2,2 & 25,6 & 36,7 & 35,6 & 4,06 \\
$\begin{array}{l}\text { Penyuluh pertanian dapat } \\
\text { menarik hati masyarakat saat } \\
\text { mensosialisasikan bidang } \\
\text { pertanian }\end{array}$ & & & & & & & \\
Rata-rata & & & & & & \\
\hline
\end{tabular}

Sumber : Data primer (Diolah), 2017

Keandalan penyuluh pertanian dalam melakukan sosialisasi kepada masyarakat, dimana responden menyatakan tidak setuju sebanyak 5,6 \%, responden menyatakan kurang setuju sebanyak $23,3 \%$, responden menyatakan setuju sebanyak $61,1 \%$ dan responden yang menyatakan sangat setuju sebanyak $10 \%$ dari total responden. Penyuluh pertanian membawa peralatan yang lengkap saat melakukan sosialisasi, dimana responden menyatakan responden menyatakan tidak setuju sebanyak $2,2 \%$, responden menyatakan kurang setuju sebanyak 25,6 \%, responden yang menyatakan setuju sebanyak $36,7 \%$ dan responden yang menyatakan sangat setuju sebanyak $35,6 \%$ dari total responden. Penyuluh pertanian dapat menarik hati masyarakat saat mensosialisasikan bidang pertanian memberikan perhatian serius terhadap anda ketika tempat penuh, responden menyatakan kurang setuju sebanyak 14,4 , setuju sebanyak $16,7 \%$, dan sangat setuju sebanyak $68,9 \%$.

Berdasarkan hasil pengamatan terhadap faktor Keandalan diperoleh nilai rata-rata sebesar $(3,79)$ yang bermakna bahwa responden menyatakan setuju bahwa variabel Kehandalan mempengaruhi Kepuasan Petani dalam pengembangan usahatani di Desa Busu Dayah Syarief Kecamatan Mutiara Kabupaten Pidie, hal ini bertentangan dengan penelitian Abubakar et al (2015) pada dimensi keandalan menunjukkan bahwa kualitas pelayanan penyuluh pertanian dalam penanganan dan pengolahan hasil ubi jalar masih rendah dan respon petani juga kurang dengan demikian dimensi tersebut diabaikan saja.

\section{Faktor Daya tanggap}

Faktor daya tanggap $\left(\mathrm{X}_{2}\right)$ merupakan salah satu variabel yang mempengaruhi Kepuasan Petani dalam pengembangan usahatani di Desa Busu Dayah Syarief Kecamatan Mutiara Kabupaten Pidie yang terdiri dari 3 item pertanyaan. Hasil pengolahan data seperti pada Tabel 3. 
Tabel 3. Indikator Faktor Daya Tanggap

\begin{tabular}{|c|c|c|c|c|c|c|}
\hline Uraian Variabel & $\begin{array}{c}\text { STS } \\
\%\end{array}$ & $\begin{array}{l}\text { TS } \\
\%\end{array}$ & $\begin{array}{c}\text { KS } \\
\%\end{array}$ & $\begin{array}{c}S \\
\%\end{array}$ & $\begin{array}{l}\text { SS } \\
\%\end{array}$ & $\begin{array}{l}\text { Rata- } \\
\text { rata }\end{array}$ \\
\hline $\begin{array}{l}\text { Daya tanggap masyarakat dalam } \\
\text { memahami apa yang telah di } \\
\text { sosialisasikan oleh penyuluh } \\
\text { pertanian }\end{array}$ & 0 & 0 & 30,0 & 64,4 & 5,6 & 3,76 \\
\hline $\begin{array}{l}\text { Mengutamakan aspek pelayanan } \\
\text { yang sangat mempengaruhi } \\
\text { perilaku orang yang mendapat } \\
\text { pelayanan }\end{array}$ & 0 & 1,1 & 25,6 & 42,2 & 31,1 & 4,03 \\
\hline $\begin{array}{l}\text { Adanya pengertian dari Penyuluh } \\
\text { terhadap Petani yang Kurang } \\
\text { mampu }\end{array}$ & 0 & 11,1 & 21,1 & 65,5 & 2,2 & 3,59 \\
\hline Rata-rata & & & & & & 3,79 \\
\hline
\end{tabular}

Sumber : Data primer (Diolah), 2017

Berdasarkan Tabel 3 di atas dapat dilihat secara jelas mengenai tanggapan responden terhadap variabel Daya tanggap masyarakat dalam memahami apa yang telah di sosialisasikan oleh penyuluh pertanian, dimana responden menyatakan kurang setuju sebanyak $30,0 \%$, responden menyatakan setuju sebanyak $64,4 \%$, dan responden menyatakan sangat setuju sebanyak 5,6 $\%$ dari total responden. Mengutamakan aspek pelayanan yang sangat mempengaruhi perilaku orang yang mendapat pelayanan, dimana responden menyatakan tidak setuju sebanyak $1,1 \%$, responden menyatakan kurang setuju sebanyak $25,6 \%$, setuju sebanyak $42,2 \%$ dan responden menyatakan sangat setuju sebanyak 31,1 \% dari total responden. Adanya pengertian dari Penyuluh terhadap Petani yang Kurang mampu, dimana responden menyatakan tidak setuju sebanyak $11,1 \%$, responden menyatakan kurang setuju sebanyak $21,1 \%$, setuju sebanyqak $65,5 \%$ dan responden menyatakan sangat setuju sebanyak 2,2 \% dari total semua responden.

Berdasarkan hasil pengamatan terhadap faktor Daya tanggap diperoleh nilai rata-rata sebesar (3.79) yang bermakna bahwa responden menyatakan setuju bahwa variabel daya tanggap mempengaruhi Kepuasan Petani dalam pengembangan usahatani di Desa Busu Dayah Syarief Kecamatan Mutiara Kabupaten Pidie. Hasil penelitian sesuai dengan penelitian Abubakar et al (2015) Dimensi daya tanggap dalam penanganan dan pengolahan hasil ubi jalar menunjukkan tingkat kepentingan petani sangat tinggi akan tetapi kualitas pelayanan penyuluh pertanian masih rendah sehingga belum adanya kepuasan petani. Dengan demikian perlu adanya perbaikan kualitas pelayanan penyuluhan pertanian. 


\section{Faktor Keyakinan}

Faktor Keyakinan $\left(X_{3}\right)$ merupakan salah satu variabel yang mempengaruhi Kepuasan Petani dalam pengembangan usahatani di Desa Busu Dayah Syarief Kecamatan Mutiara Kabupaten Pidie yang terdiri dari 3 item pertanyaan. Hasil pengolahan data seperti pada Tabel 4.

Dengan adanya penyuluhan petani mendapatkan wawasan baru, dimana responden tidak setuju sebanyak 5,6 \%, responden menyatakan kurang setuju sebanyak $28,9 \%$, setuju sebanyak $64,4 \%$ dan responden menyatakan sangat setuju sebanyak 1,1 \% dari total responden. Dengan adanya penyuluhan petani yakin dapat meningkatkan hasil pertaniannya, dimana responden tidak setuju sebanyak 6,7 \%, responden menyatakan kurang setuju sebanyak 16,7 \%, setuju sebamyak 45,6 \% dan responden menyatakan sangat setuju sebanyak $31,1 \%$ dari total responden. Petani senang dapat bekerjasama dengan pihak penyuluhan dalam mengembangkan usahatani, dimana responden menyatakan tidak setuju sebanyak $14,4 \%$, responden kurang setuju sebanyak $22,2 \%$, setuju sebanyak 62,2 \% dan responden menyatakan sangat setuju sebanyak 1,1 \% dari total responden. Berdasarkan hasil pengamatan terhadap faktor Keyakinan diperoleh nilai rata-rata sebesar $(3,706)$ yang bermakna bahwa responden menyatakan setuju bahwa variabel Keyakinan mempengaruhi Kepuasan Petani dalam pengembangan usahatani di Desa Busu Dayah Syarief Kecamatan Mutiara Kabupaten Pidie hal ini sejalan dengan penelitian Abubakar et al (2015).

\section{Tabel 4. Indikator Faktor Keyakinan}

\begin{tabular}{lcccccc}
\hline Uraian Variabel & STS & TJ & KS & S & SS & $\begin{array}{l}\text { Rata- } \\
\text { rata }\end{array}$ \\
\cline { 2 - 6 } & $\mathbf{0}$ & $\mathbf{0}$ & $\mathbf{0}$ & $\mathbf{\%}$ & $\mathbf{\%}$ & 3,61 \\
\hline $\begin{array}{l}\text { Dengan adanya penyuluhan petani } \\
\text { mendapatkan wawasan baru }\end{array}$ & 0 & 5,6 & 28,9 & 64,4 & 1,1 & \\
$\begin{array}{l}\text { Dengan adanya penyuluhan petani } \\
\text { yakin dapat meningkatkan hasil } \\
\text { pertaniannya }\end{array}$ & 0 & 6,7 & 16,7 & 45,6 & 31,1 & 4,01 \\
$\begin{array}{l}\text { Petani senang dapat bekerjasama } \\
\text { dengan pihak penyuluhan dalam } \\
\text { mengembangkan usahatani }\end{array}$ & 0 & 14,4 & 22,2 & 62,2 & 1,1 & 3,50 \\
Rata- rata & & & & & & 3,70 \\
\hline
\end{tabular}

Sumber : Data primer (Diolah), 2017

\section{Faktor Empati}

Faktor Empati merupakan salah satu variabel yang mempengaruhi Kepuasan Petani dalam pengembangan usahatani di Desa Busu Dayah Syarief Kecamatan Mutiara Kabupaten Pidie yang terdiri dari 3 item pertanyaan. Hasil pengolahan data seperti pada Tabel 5. 
Petani mendapatkan ilmu baru dalam bertani dengan kehadiran penyuluh di gampong mereka, dimana responden tidak setuju sebanyak $6,7 \%$, responden menyatakan kurang setuju sebanyak $23,3 \%$, setuju sebanyak $66,7 \%$ dan responden menyatakan sangat setuju sebanyak 3,3 \% dari total responden. Penyuluh Mempunyai rasa tanggungjawab atas pengembangan usaha tani, dimana responden tidak setuju sebanyak $1,1 \%$, responden menyatakan kurang setuju sebanyak $33,3 \%$, setuju sebanyak $43,3 \%$ dan responden menyatakan sangat setuju sebanyak $22,2 \%$ dari total responden. Petani sangat membutuhkan sosialisasi untuk mengembangkan usahatani, dimana responden tidak setuju sebanyak $13,3 \%$, responden menyatakan kurang setuju sebanyak $14,4 \%$, setuju sebanyak $61,1 \%$ dan responden menyatakan sangat setuju sebanyak $11,1 \%$ dari total responden. Berdasarkan hasil pengamatan terhadap faktor Empati diperoleh nilai rata-rata sebesar $(3,75)$ yang bermakna bahwa responden menyatakan setuju bahwa variabel Empati mempengaruhi Kepuasan Petani dalam pengembangan usahatani di Desa Busu Dayah Syarief Kecamatan Mutiara Kabupaten Pidie.

Tabel 5. Indikator Faktor Empati

\begin{tabular}{lcccccc}
\hline Uraian Variabel & STS & TJ & KS & S & SS & $\begin{array}{c}\text { Rata- } \\
\text { rata }\end{array}$ \\
\cline { 2 - 6 } & $\%$ & $\%$ & $\%$ & $\%$ & $\%$ & 3,67 \\
\hline $\begin{array}{l}\text { Petani mendapatkan ilmu baru } \\
\text { dalam bertani dengan kehadiran } \\
\text { penyuluh di gampong mereka }\end{array}$ & 0 & 6,7 & 23,3 & 66,7 & 3,3 & \\
$\begin{array}{l}\text { Penyuluh Mempunyai rasa } \\
\text { tanggungjawab atas pengembangan }\end{array}$ & 0 & 1,1 & 33,3 & 43,3 & 22,2 &, 87 \\
$\begin{array}{l}\text { usaha tani } \begin{array}{l}\text { Petani sangat membutuhkan } \\
\text { sosialisasi untuk mengembangkan }\end{array} \\
\begin{array}{l}\text { usahatani } \\
\text { Rata-rata }\end{array}\end{array} \quad 0 \quad 13,3$ & 14,4 & 61,1 & 11,1 & 3,70 \\
\hline
\end{tabular}

Sumber : Data primer (Diolah), 2017

\section{Faktor Bukti Fisik}

Faktor Bukti Fisik $\left(X_{5}\right)$ merupakan salah satu variabel yang mempengaruhi Kepuasan Petani dalam pengembangan usahatani di Desa Busu Dayah Syarief Kecamatan Mutiara Kabupaten Pidie yang terdiri dari 3 item pertanyaan. Hasil pengolahan data seperti pada Tabel 6.

Petani sangat membutuhkan sosialisasi untuk mengembangkan usahatani, dimana responden tidak setuju sebanyak 3,3\%, responden menyatakan kurang setuju sebanyak $26,7 \%$, setuju sebanyak $55,6 \%$ dan responden menyatakan sangat setuju sebanyak $14,4 \%$ dari total responden. Penyuluh pertanian memberikan pengalaman yang bermanfaat kepada petani, dimana responden tidak setuju sebanyak $2,2 \%$, responden menyatakan kurang 
setuju sebanyak $14,4 \%$, setuju sebanyak $51,1 \%$ dan responden menyatakan sangat setuju sebanyak $21,1 \%$ dari total responden. Penyuluh pertanian sering mengontrol usaha petani setelah memberikan sosialisasinya, dimana responden tidak setuju sebanyak $10,0 \%$, responden menyatakan kurang setuju sebanyak $21,1 \%$, setuju sebanyak $58,9 \%$ dan responden menyatakan sangat setuju sebanyak $10,0 \%$ dari total responden.

Berdasarkan hasil pengamatan terhadap faktor Bukti Fisik diperoleh nilai rata-rata sebesar $(3,803)$ yang bermakna bahwa responden menyatakan setuju bahwa variabel Bukti Fisik mempengaruhi Kepuasan Petani dalam pengembangan usahatani di Desa Busu Dayah Syarief Kecamatan Mutiara Kabupaten Pidie.

\section{Tabel 6. Indikator Faktor Bukti Fisik}

\begin{tabular}{|c|c|c|c|c|c|c|}
\hline \multirow{2}{*}{ Uraian Variabel } & STS & TJ & KS & $S$ & SS & \multirow{2}{*}{$\begin{array}{l}\text { Rata- } \\
\text { rata }\end{array}$} \\
\hline & $\%$ & $\%$ & $\%$ & $\%$ & $\%$ & \\
\hline $\begin{array}{l}\text { Petani sangat membutuhkan sosialisasi } \\
\text { untuk mengembangkan usahatani }\end{array}$ & 0 & 3,3 & 26,7 & 55,6 & 14,4 & 3,81 \\
\hline $\begin{array}{l}\text { Penyuluh pertanian memberikan } \\
\text { pengalaman yang bermanfaat kepada } \\
\text { petani }\end{array}$ & 0 & 2,2 & 25,6 & 51,1 & 21,1 & 3,91 \\
\hline $\begin{array}{l}\text { Penyuluh pertanian sering mengontrol } \\
\text { usaha petani setelah memberikan } \\
\text { sosialisasinya }\end{array}$ & 0 & 10,0 & 21,1 & 58,9 & 10,1 & 3,69 \\
\hline Rata-rata & & & & & & 3,80 \\
\hline
\end{tabular}

Sumber : Data primer (Diolah), 2017

\section{Variabel Kepuasan Petani}

Kepuasan Petani merupakan besarnya konsumsi dan frekuensi pembelian yang dilakukan oleh seorang pelanggan terhadap suatu perusahaan. Dan mereka berhasil menemukan bahwa kualitas pelayanan yang terdiri dari kehandalan, daya tanggap, Keyakinan, empati dan bukti fisik mempunyai hubungan yang positif dengan Kepuasan Petani. Untuk lebih jelas tingkat kesetujuan terhadap pernyataan yang berhubungan dengan variabel Kepuasan Petani dapat dilihat pada tabel 7. Terjadi peningkatan usahatani setelah mendapatkan penyuluhan pertanian, dimana responden menyatakan kurang setuju sebanyak $27,8 \%$, responden menyatakan setuju sebanyak $55,6 \%$ dan responden menyatakan sangat setuju sebanyak $16,7 \%$ dari total responden. Petani merasa puas dengan adanya penyuluhan di gampong mereka, saya akan memprorioritaskan pruduk Soklin, dimana responden menyatakan kurang setuju sebanyak $7,8 \%$, responden menyatakan setuju sebanyak $23,3 \%$, dan responden menyatakan sangat setuju sebanyak $68,9 \%$ dari total responden. 
Tabel 7. Variabel Kepuasan Petani (Y)

\begin{tabular}{|c|c|c|c|c|c|c|}
\hline \multirow{2}{*}{ Uraian Variabel } & STS & $\mathrm{TJ}$ & KS & $S$ & SS & \multirow{2}{*}{$\begin{array}{l}\text { Rata- } \\
\text { rata }\end{array}$} \\
\hline & $\%$ & $\%$ & $\%$ & $\%$ & $\%$ & \\
\hline $\begin{array}{l}\text { Terjadi peningkatan usahatani setelah } \\
\text { mendapatkan penyuluhan pertanian }\end{array}$ & 0 & 0 & 27,8 & 55,6 & 16,7 & 3,89 \\
\hline $\begin{array}{l}\text { Petani merasa puas dengan adanya } \\
\text { penyuluhan di gampong mereka }\end{array}$ & 0 & 0 & 7,8 & 23,3 & 68,9 & 4,61 \\
\hline $\begin{array}{l}\text { Setelah bekerjasama dengan penyuluh } \\
\text { pertanian terjadi peningkatan laba usaha }\end{array}$ & 0 & 0 & 18,9 & 12,2 & 68,9 & 3,50 \\
\hline $\begin{array}{l}\text { Penjualan usaha petani semakin } \\
\text { meningkat karena adanya tambahan } \\
\text { modal dari kredit melalui dinas pertanian }\end{array}$ & 0 & 0 & 24,4 & 32,2 & 43,3 & 4,19 \\
\hline $\begin{array}{l}\text { Dengan adanya pinjaman modal petani } \\
\text { dapat meningkatkan produksi dalam } \\
\text { mengembangkan usaha pertanian }\end{array}$ & 0 & 1,1 & 27,8 & 68,9 & 2,2 & 3,72 \\
\hline Rata-rata & & & & & & 4,18 \\
\hline
\end{tabular}

Sumber : Data Primer Penelitian (Diolah), 2017

Setelah bekerjasama dengan penyuluh pertanian terjadi peningkatan laba usaha, dimana responden menyatakan kurang setuju sebanyak 18,9\%, responden menyatakan setuju sebanyak $12,2 \%$, dan responden menyatakan sangat setuju sebanyak $68,9 \%$ dari total responden. Penjualan usaha petani semakin meningkat karena adanya tambahan modal dari kredit melalui dinas pertanian, dimana responden menyatakan kurang setuju sebanyak $24,4 \%$, responden menyatakan setuju sebanyak $32,2 \%$, dan responden menyatakan sangat setuju sebanyak $43,3 \%$ dari total responden. Dengan adanya pinjaman modal petani dapat meningkatkan produksi dalam mengembangkan usaha pertanian, dimana responden menyatakan tidak setuju sebanyak $1,1 \%$, responden menyatakan kurang setuju sebanyak $27,8 \%$, dan responden menyatakan setuju sebanyak $68,9 \%$ dan responden menyatakan sangat setuju sebanyak 2,2 \% dari total responden. Berdasarkan hasil pengamatan terhadap variabel Kepuasan Petani diperoleh nilai rata-rata sebesar (4.18), sehingga penilaian responden terhadap variabel Kepuasan Petani dipengaruhi oleh variabel-variabel kehandalan, daya tanggap, Keyakinan, empati dan bukti fisik.

\section{Analisis Pengaruh Kualitas Pelayanan terhadap Kepuasan Petani dalam Pengembangan Usahatani}

Untuk mengetahui pengaruh variable Kehandalan $\left(X_{1}\right)$, Daya tanggap $\left(X_{2}\right)$, Keyakinan $\left(X_{3}\right)$, Empati $\left(X_{4}\right)$, dan Bukti Fisik $\left(X_{5}\right)$ terhadap Kepuasan Petani dalam pengembangan usahatani di Desa Busu Dayah Syarief Kecamatan Mutiara Kabupaten Pidie, maka dilakukan analisis data melalui regresi linear berganda. Dimana hasilnya dapat dilihat pada Tabel berikut: 
Tabel 8. Pengaruh Masing-masing Variabel Independen Terhadap Variabel Dependen

\begin{tabular}{|c|c|c|c|c|c|c|}
\hline Nama Variabel & B & $\begin{array}{l}\text { Standar } \\
\text { Error }\end{array}$ & Beta & thitung & $\mathrm{t}$ tabel & Sign \\
\hline Konstanta & 2.816 & 0.446 & & 6.318 & 1,663 & 0.000 \\
\hline Kehandalan & 0.226 & 0.114 & 0.153 & 1.978 & 1,663 & 0.051 \\
\hline Daya tanggap & 0.397 & 0.128 & 0.239 & 3.088 & 1,663 & 0.003 \\
\hline Keyakinan & 0.247 & 0.082 & 0.162 & 3.007 & 1,663 & 0.003 \\
\hline Empati & 0.307 & 0.097 & 0.190 & 3.158 & 1,663 & 0.002 \\
\hline Bukti Fisik & 0.422 & 0.125 & 0.273 & 3.373 & 1,663 & 0.001 \\
\hline Koefisien Korelasi (R) & & 0,978 & & & & \\
\hline Koefisien Determinasi (R & & 0,957 & & & & \\
\hline Adjusted R Squares & & 0,954 & & & & \\
\hline$F_{\text {hitung }}$ & & 371.811 & & & & \\
\hline $\mathrm{F}$ tabel & & & & & & \\
\hline Sign F & & 0,000 & & & & \\
\hline
\end{tabular}

Sumber: Data Primer Penelitian (Diolah), 2017

Dari output SPSS pada Tabel 8 dapat dijelaskan sebagai berikut:

Nilai konstanta sebesar 2.816 artinya jika Kehandalan $\left(X_{1}\right)$, Daya tanggap $\left(X_{2}\right)$, Keyakinan $\left(X_{3}\right)$, Empati $\left(X_{4}\right)$, dan Bukti Fisik $\left(X_{5}\right)$ dianggap konstan, maka Kepuasan Petani dalam pengembangan usahatani di Desa Busu Dayah Syarief Kecamatan Mutiara Kabupaten Pidie adalah sebesar 2.816. Nilai koefisien regresi Kehandalan sebesar 0.226 dapat diartikan bahwa setiap 1\% kenaikan Kehandalan $\left(\mathrm{X}_{1}\right)$ akan meningkatkan Kepuasan Petani dalam pengembangan usahatani di Desa Busu Dayah Syarief Kecamatan Mutiara Kabupaten Pidie sebesar 22,6\%. Ini berarti terjadi Kepuasan Petani dalam pengembangan usahatani di Desa Busu Dayah Syarief Kecamatan Mutiara Kabupaten Pidie.

Nilai koefisien regresi Daya tanggap sebesar 0.397 dapat diartikan bahwa setiap 1\% kenaikan Daya tanggap $\left(X_{2}\right)$ akan meningkatkan Kepuasan Petani dalam pengembangan usahatani di Desa Busu Dayah Syarief Kecamatan Mutiara Kabupaten Pidie sebesar 39,7 \%. Ini berarti terjadi Kepuasan Petani dalam pengembangan usahatani di Desa Busu Dayah Syarief Kecamatan Mutiara Kabupaten Pidie. Nilai koefisien regresi Keyakinan sebesar 0.247 dapat diartikan bahwa setiap 1\% kenaikan Keyakinan $\left(X_{3}\right)$ akan meningkatkan Kepuasan Petani dalam pengembangan usahatani di Desa Busu Dayah Syarief Kecamatan Mutiara Kabupaten Pidie sebesar 24,7 \%. Ini berarti terjadi Kepuasan Petani dalam pengembangan usahatani di Desa Busu Dayah Syarief Kecamatan Mutiara Kabupaten Pidie.

Nilai koefisien regresi Empati sebesar 0.307 dapat diartikan bahwa setiap $1 \%$ kenaikan Empati $\left(X_{4}\right)$ akan meningkatkan Kepuasan Petani dalam pengembangan usahatani di Desa Busu Dayah Syarief Kecamatan Mutiara 
Kabupaten Pidie sebesar 30,7 \%. Ini berarti terjadi Kepuasan Petani dalam pengembangan usahatani di Desa Busu Dayah Syarief Kecamatan Mutiara Kabupaten Pidie. Nilai koefisien regresi Bukti Fisik sebesar 0.422 dapat diartikan bahwa setiap $1 \%$ kenaikan Bukti Fisik $\left(X_{5}\right)$ akan meningkatkan Kepuasan Petani dalam pengembangan usahatani di Desa Busu Dayah Syarief Kecamatan Mutiara Kabupaten Pidie sebesar 42,2 \%. Ini berarti terjadi Kepuasan Petani dalam pengembangan usahatani di Desa Busu Dayah Syarief Kecamatan Mutiara Kabupaten Pidie.

Berdasarkan hasil analisis di atas dapat disimpulkan bahwa dari kelima variabel yang diteliti, ternyata variabel Keyakinan $\left(X_{3}\right)$ mempunyai pengaruh yang paling dominan sebesar $0.422 \%$ terhadap Kepuasan Petani dalam pengembangan usahatani di Desa Busu Dayah Syarief Kecamatan Mutiara Kabupaten Pidie.

Hubungan antara variabel dependen dan independen yaitu masingmasing variabel Kehandalan $\left(X_{1}\right)$, Daya tanggap $\left(X_{2}\right)$, Keyakinan $\left(X_{3}\right)$, Empati $\left(X_{4}\right)$, dan Bukti Fisik $\left(X_{5}\right)$ terhadap Kepuasan Petani dalam pengembangan usahatani di Desa Busu Dayah Syarief Kecamatan Mutiara Kabupaten Pidie dengan indeks korelasi sebesar 0,978 atau 97,8 \% Ini berarti hubungan tersebut sangat kuat. Kemudian indeks determinasi masing-masing variabel Kehandalan $\left(X_{1}\right)$, Daya tanggap $\left(X_{2}\right)$, Keyakinan $\left(X_{3}\right)$, Empati $\left(X_{4}\right)$, dan Bukti Fisik $\left(X_{5}\right)$ sebesar 0,957 atau $95,7 \%$, ini berarti ke 5 variabel berpengaruh secara signifikan terhadap Kepuasan Petani dalam pengembangan usahatani di Desa Busu Dayah Syarief Kecamatan Mutiara Kabupaten Pidie, dan sebesar 4,3 \% yang dipengaruhi oleh variabel lain yang tidak diteliti dalam penelitian ini.

\section{SIMPULAN DAN SARAN}

\section{Simpulan}

Kepuasan petani terhadap pelayanan penyuluh dalam pengembangan usahatani di Kabupaten Pidie berdasarkan hasil penelitian terhadap variabel Kepuasan Petani diperoleh nilai rata-rata sebesar (4.18), sehingga penilaian responden terhadap variabel Kepuasan Petani dipengaruhi oleh variabelvariabel kehandalan, daya tanggap, Keyakinan, empati dan bukti fisik.

Hubungan kualitas pelayanan penyuluh pertanian terhadap pengembangan usaha tani di Kabupaten Pidie berdasarkan hasil analisis disimpulkan bahwa dari kelima variabel yang diteliti, ternyata variabel Keyakinan $\left(X_{3}\right)$ mempunyai pengaruh yang paling dominan sebesar $0.422 \%$ terhadap Kepuasan Petani dalam pengembangan usahatani di Desa Busu Dayah Syarief Kecamatan Mutiara Kabupaten Pidie. Hubungan antara variabel dependen dan independen yaitu masing-masing variabel Kehandalan $\left(X_{1}\right)$, Daya tanggap $\left(X_{2}\right)$, Keyakinan $\left(X_{3}\right)$, Empati $\left(X_{4}\right)$, dan Bukti Fisik $\left(X_{5}\right)$ terhadap Kepuasan Petani dalam pengembangan usahatani di Desa Busu Dayah Syarief 
Kecamatan Mutiara Kabupaten Pidie dengan indeks korelasi sebesar 0,978 atau $97,8 \%$ Ini berarti hubungan tersebut sangat kuat. Kemudian indeks determinasi masing-masing variabel Kehandalan $\left(X_{1}\right)$, Daya tanggap $\left(X_{2}\right)$, Keyakinan $\left(X_{3}\right)$, Empati $\left(X_{4}\right)$, dan Bukti Fisik $\left(X_{5}\right)$ sebesar 0,957 atau 95,7 \%, ini berarti ke 5 variabel berpengaruh secara signifikan terhadap Kepuasan Petani dalam pengembangan usahatani di Desa Busu Dayah Syarief Kecamatan Mutiara Kabupaten Pidie, dan sebesar 4,3\% yang dipengaruhi oleh variabel lain yang tidak diteliti dalam penelitian ini.

\section{Saran}

1. Untuk memaksimalkan dan meningkatkan kualitas pelayanan penyuluh pertanian terhadap pengembangan usaha tani di Kabupaten Pidie untuk variabel yang kurang dominan perlu dilakukan upaya upaya perbaikan terhadap variabel tersebut.

2. Perlu penelitian lebih lanjut dengan beberapa karakeristik lain yang diduga berhubungan dengan kualitas pelayanan penyuluh pertanian.

\section{DAFTAR PUSTAKA}

Abubakar dan Amelia, Nani Siregar. 2015. Kualitas Pelayanan Penyuluh Pertanian dan Kepuasan Petani dalam Penanganan dan Pengolahan Hasil Ubi Jalar. Jurnal Penyuluhan Pertanian Vol 5 No. 1.

Asayehegn K, Weldegebrial G, Kaske D. 2012. Effectiveness of Development

Agents' Performances in Agricultural Technology Dissemination: The Case of Southern Nations Nationalities and Peoples Regional State (SNNPRS), Ethiopia. Journal of Agricultural Extension and Rural Development. 4(17): 446-455.

Arikunto. 2006: 131). Prosedur Penelitian Suatu Pendekatan Praktik, Ed Revisi VI, Penerbit PT Rineka Cipta, Jakarta.

A.w. van de Ban dkk. 2009 Penyuluhan Pertanian. Penerbit Kanisius. Yogyakarta.

Bitnar. 2007. Service Marketing (3rd ed.), Tata McGraw Hill, New Delhi.

Daryanto. 2014. Pembelajran Tematik, Terpadu, Terintegrasi. Gava Media, Jogjakarta

Departemen Pertanian. 2002. Teknologi Tepat Guna: Budi Daya Petrenakan, Jakarta.

Hamzah. 2011. Faktor Penentu Kinerja Penyuluh Pertanian di Kota Tidore Kepulauan Provinsi Maluku Utara. Jurnal Forum Pascasarjana. 34(4): 102-110.

Manyamsari I, Mujiburrahmad. 2014. Karakteristik petani dan hubungannya dengan kompetensi petani lahan sempit. Agrisep 15(2): 58-74 
Ikhsan, M. 2013. Kualitas Pelayanan Penyuluhan Pertanian dan Kepuasan Petani dalam Pengembangan Usahatani. Universitas Syiah Kuala

Kotler. 2004. Dasar-dasar Pemasaran. Jilid 1, Alih Bahasa Alexander Sindoro dan Benyamin Molan. Penerbit Prenhalindo. Jakarta

Margono. 2004. Metodelogi penelitian pendidikan. Rineka Cipta, Jakarta

Mujiburrahmad. 2014. Kinerja Penyuluh Pertanian di Kabupaten Pidie Provinsi

Aceh dalam Melaksanakan Tugas dan Fungsinya. Jurnal Penyuluhan. 10

(2). ISSN 1858-2664. Bogor: Institut Pertanian Bogor

Nazir. 2011. Metode Penelitian. Ghalia Indonesia, Jakarta

Puspadi. 2010. Model Perilaku Kerja Penyuluh Pertanian. BPTP.

Undang-undang Republik Indonesia Nomor 16 Tahun 2006 Tentang Sistem

Penyuluhan Pertanian, Perikanan dan Kehutanan.

Sekaran, 2009, Metodologi Penelitian untuk Bisnis, Edisi 4, Buku 2, Salemba Empat, Jakarta.

Sezgin A, Eren TK, Atsan T. 2010. Factors Influencing Agricultural Extension

Staff Effectiveness in Public Institutions in Erzurum, Turkey. African

Journal of Business Management. 4(18): 4106-4109.

Slamet, Margono 2006. Membentuk Pola Perilaku Manusia Pembangunan, IPB Press, Bogor.

Sudjana, Nana dan Ibrahim. 2004: 85. Penelitian Dan Penilaian Pendidikan, Sinar Baru Algensindo, Bandung.

Setiana, L. 2005 Teknik Penyuluhan Dan Pemberdayaan Masyarakat. Ghalia Indonesia, Bogor.

Subagio et al. 2008. Proses Produksi Mocal.http://tepungmocal.ning.com.

Diakses pada 3 Oktober 2008)

Sugiyono. 2003. Metode Penelitian Bisnis. Edisi 1, Alfabeta, Bandung

Tjitropranoto. 2005. Penyuluhan Pertanian: Masa Kini dan Masa Depan."

Dalam: Membentuk Pola Perilaku Manusia Pembangunan. Diedit oleh: Ida Yustina dan Adjat Sudradjat. Bogor: IPB Press.

Tjiptono, 2012. Pemasaran Strategik. Yogyakarta.

Undang-undang Republik Indonesia Nomor 16 Tahun 2006 Tentang Sistem Penyuluhan Pertanian, Perikanan dan Kehutanan.

Zahara, Rita. 2015. Analisis Tingkat Kepuasan Petani Terhadap Kinerja Penyuluh Pertanian Lapangan (PPL) di Kabupaten Pidie. Jurnal Agrisep. Prodi Agribisnis. Universitas Syiah Kuala. 